\title{
Effectiveness of Prenatal Yoga on Sleep Quality and Reduction of Anxiety During Pregnancy: A Meta-Analysis
}

\author{
Shiva Aflahiyah'), Didik Gunawan Tamtono², Hanung Prasetya3) \\ 1)Masters Program in Public Health, Universitas Sebelas Maret \\ 2)Faculty of Medicine, Universitas Sebelas Maret \\ 3)Study Program of Acupuncture, Health Polytechnics, Ministry of Health, Surakarta
}

\section{ABSTRACT}

Background:Anxiety and sleep disorders during pregnancy are often experienced during pregnancy. Discomfort during pregnancy can be overcome non-pharmacologically, one of which is prenatal Yoga. This study aimed to estimate the mean effectiveness of prenatal Yoga on sleep quality and decrease anxiety during pregnancy.

Subjects and Method:This study used a systematic review and meta-analysis study design. The time of the selected test results was between 2005 and 2020. The search for articles was carried out for 1 month. Study data was searched from databases: PubMed, Science Direct, Springer Link, Google Scholar, Cochrane Library. The inclusion criteria in this study were full-text articles and in English. The study design used a randomized controlled trial. Search for articles using the PICO model. The population in this study were pregnant women, intervention in the form of prenatal yoga exercises, comparison without prenatal yoga exercises, and the outcome in anxiety and sleep quality. Data processing was carried out by the
Review Manager (RevMan 5.3) by calculating the standardized mean difference to determine the research model that was combined and formed the final meta-analysis result.

Results:A total of 10 articles were reviewed in this study on the effectiveness of prenatal Yoga on anxiety and as many as 3 articles on sleep quality. Studies showed that prenatal Yoga significantly reduce anxiety during pregnancy $(\mathrm{SMD}=-0.84 ; 95 \% \mathrm{CI}-1.53$ to $-0.16 \mathrm{p}=0.020)$. Prenatal yoga could also reduce sleep disorders and improve sleep quality as shown in statistics $(\mathrm{SMD}=-1.13$; 90\% CI -2.06 to $-0.21 \mathrm{p}=0.020)$.

Conclusion:Prenatal Yoga can reduce anxiety and improve sleep quality.

Keywords: anxiety, sleeping quality, prenatal Yoga, pregnancy

\section{Correspondence:}

Shiva Aflahiyah. Masters Program in Public Health, Universitas Sebelas Maret. Jl. Ir. Sutami 36A, Surakarta 57126, Central Java. Email: shivaafla@gmail.com.

Cite this as:

Aflahiyah S, Tamtomo DG, Prasetya H (2020). Effectiveness of Prenatal Yoga on Sleep Quality and Reduction of Anxiety During Pregnancy: A Meta-Analysis. J Matern Child Health. 05(06): 629-640. https://doi.org/10.26911/thejmch.2020.05.06.03.

cc (i) (-) Journal of Maternal and Child Health is licensed under a Creative Commons EY AC SA Attribution-Non Commercial-Share Alike 4.0 International License.

\section{BACKGROUND}

Discomfort during pregnancy results from changes, both physiologically and psychologically. Psychological changes that are felt by pregnant women, one of which is anxiety. According to Uguz et al. (2019), it was found that around $\mathbf{1 8 . 2 \%}$ of pregnant women experience anxiety during pregnancy. According to several studies, the level of an- xiety during pregnancy is found in Canada around 23\%, in Germany $15.6 \%$, and in Pakistan around 49\% (Martini et al., 2015; Waqas et al., 2015; Norhayati et al., 2015 in Silva et al., 2015) al., 2017).

Anxiety can affect the mother's health, hamper fetal development, and experience emotional disturbances at birth. Besides, anxiety during pregnancy affects 
many factors, one of which is the mother's sleep (Lomans et al., 2013). A study conducted by Zwan et al. (2017) found that pregnant women with shorter sleep duration had a higher incidence of anxiety. Good quality sleep during pregnancy has a positive effect on mental health (Beebe \& Lee, 2007 in Beddoe et al., 2010).

Exercise during pregnancy can improve stamina, make better sleep, improve mood, and reduce anxiety (Murkoff, 2012). This is because exercise can release endorphins from the brain. One type of exercise that can be applied to reduce anxiety and improve sleep quality is prenatal yoga (Field et al., 2013; Hollenbach et al., 2013).

Prenatal Yoga is a sport that can harmonize the body, mind, and spirit by building strong posture and training muscles to be flexible and strong (Lebang, 2014; Mander, 2003 in Resmi et al., 2017). Prenatal Yoga can reduce the abnormal activity of the Maternal Sympathetic Adrenal Medullary (SAM) and the HPA Axis (Hypothalamus Pituitary Adrenal), which produce the hormone cortisol, which can trigger depression and anxiety (Satyapriya, 2013). In addition, prenatal Yoga can also improve the quality of sleep for pregnant women. This is evidenced by a study conducted by Kundarti et al. (2020), which stated that the research results found that doing prenatal Yoga for 8 weeks with a duration of 90 minutes can reduce anxiety, the hormone cortisol and improve sleep quality in pregnant women.

The study data will be analyzed using systematic review and meta-analysis as a systematic review with statistical techniques to calculate several studies' conclusions.

\section{SUBJECTS AND METHOD}

\section{Study Design}

This study used a systematic review and meta-analysis study design. This study used secondary data in the form of data from previous study results. The time from the selected test results was between 2005 and 2020. Article searches would be carried out for a maximum of 1 month. The study data was searched from a systematic and comprehensive database, including PubMed, Science Direct, Springer Link, Google Scholar, Chocrane Library. By using the search keywords "Prenatal Yoga" OR "Anxiety" OR "Quality Sleep" OR "Sleep" "Pregnant Women" OR "During Pregnancy" AND "Randomized Controlled Trial."

\section{Inclusion Criteria}

The inclusion criteria in this study were English full-text articles. The study design used a randomized controlled trial. The research subjects were pregnant women. Selected articles discussed prenatal Yoga with the outcome of anxiety and sleep quality during pregnancy.

\section{Exclusion Criteria}

The articles published in this study were articles with study designs with non-RCT studies and were published before 2005 .

\section{Operational Definition of Variables}

The article search was carried out by considering the eligibility criteria defined using the PICO model. The population in this study were pregnant women, intervention in the form of prenatal yoga exercises, comparison without prenatal yoga exercises, and the outcome in anxiety and sleep quality.

Anxiety was a psychological problem most often faced by women during pregnancy, especially women who were pregnant for the first time. Anxiety in pregnancy was a reflection of stress. The research instrument used an anxiety questionnaire with a continuous measuring scale. 
Sleep quality was obtained when sleep disturbances experienced during pregnancy decrease. Sleep disturbance during pregnancy was a common complaint about women during pregnancy. These disorders are the result of physiological and hormonal changes, which affect during and after pregnancy. The instrument used was a sleep quality questionnaire with a continuous measuring scale.

Yoga was a mind and body practice that includes stretching and posture exercises (asanas) combined with deep breathing (pranayama) and meditation. Yoga was a moderate-intensity physical activity for pregnant women. The instrument used was a prenatal yoga questionnaire with a categorical measuring scale.

\section{Data Analysis}

Data processing was carried out by a Review Manager (RevMan 5.3) by calculating the standardized mean difference to determine which research models were combined and formed the final meta-analysis result.

\section{RESULTS}

The process of searching for articles by searching through a database with journals can be seen in Figure 1. Figure 2 shows the areas where articles were taken according to the inclusion criteria. Articles were obtained from 2 continents, namely North America, Asia, and Australia.

Assessment of the research quality in a randomized control trial used the Critical Appraisal CEBMa (Center for EvidenceBased Medicine). The assessment of study quality used CEBMa consists of 12 questions: 1) Does this study discuss a clear research focus? 2) Is the Randomized Controlled Trial research method suitable for answering research questions? 3) Are there enough subjects in the study to determined that the findings were not by chance? 4)
Were the subjects randomly allocated to the experimental and control groups? If not, could this lead to bias? 5) Were inclusion/exclusion criteria used? 6) Were the two groups comparable at the start of the study? 7) Are objective and unbiased outcome criteria used? 8) Are measurement methods used are objective and validated in measuring the results? If not, were the results assessed by someone unaware of the group assignment (i.e., what was the assessment on blinding)? 9) Is the effect size practically relevant? 10) How precise is the estimated effect? Are there any confidence intervals? 11) Could any confounding factors have not been taken into account? 12) Can the results be applied to your study? Then given a scoring of each question with 1 saying yes and o saying no.

Based on the results of the forest plot on the effectiveness of prenatal Yoga on reducing anxiety (Figure 3), prenatal yoga practice reduced anxiety 0.84 times in pregnant women compared to without prenatal Yoga, and it was statistically significant $(\mathrm{p}=0.020)$.

The heterogeneity of the study data showed I $2=95 \%$. The distribution of the data was stated to be heterogeneous (random effect model). Meanwhile, the forest plot results on the effectiveness of prenatal Yoga on sleep quality (Figure 4) showed that prenatal yoga practice increased 1.13 times the quality of sleep in pregnant women compared to without prenatal Yoga. It was statistically significant $(\mathrm{p}=0.020)$. The study data's heterogeneity showed I $2=90 \%$ so that the distribution of the data was stated to be heterogeneous (random effect model).

The funnel plot on prenatal Yoga's effectiveness on reducing anxiety (Figure 5) showed a publication bias characterized by an asymmetry of the right and left plots 
Aflahiyah et al./ Effectiveness of Prenatal Yoga on Sleep Quality and Reduction of Anxiety

where 6 plots were on the right and 4 plots

were on the left.

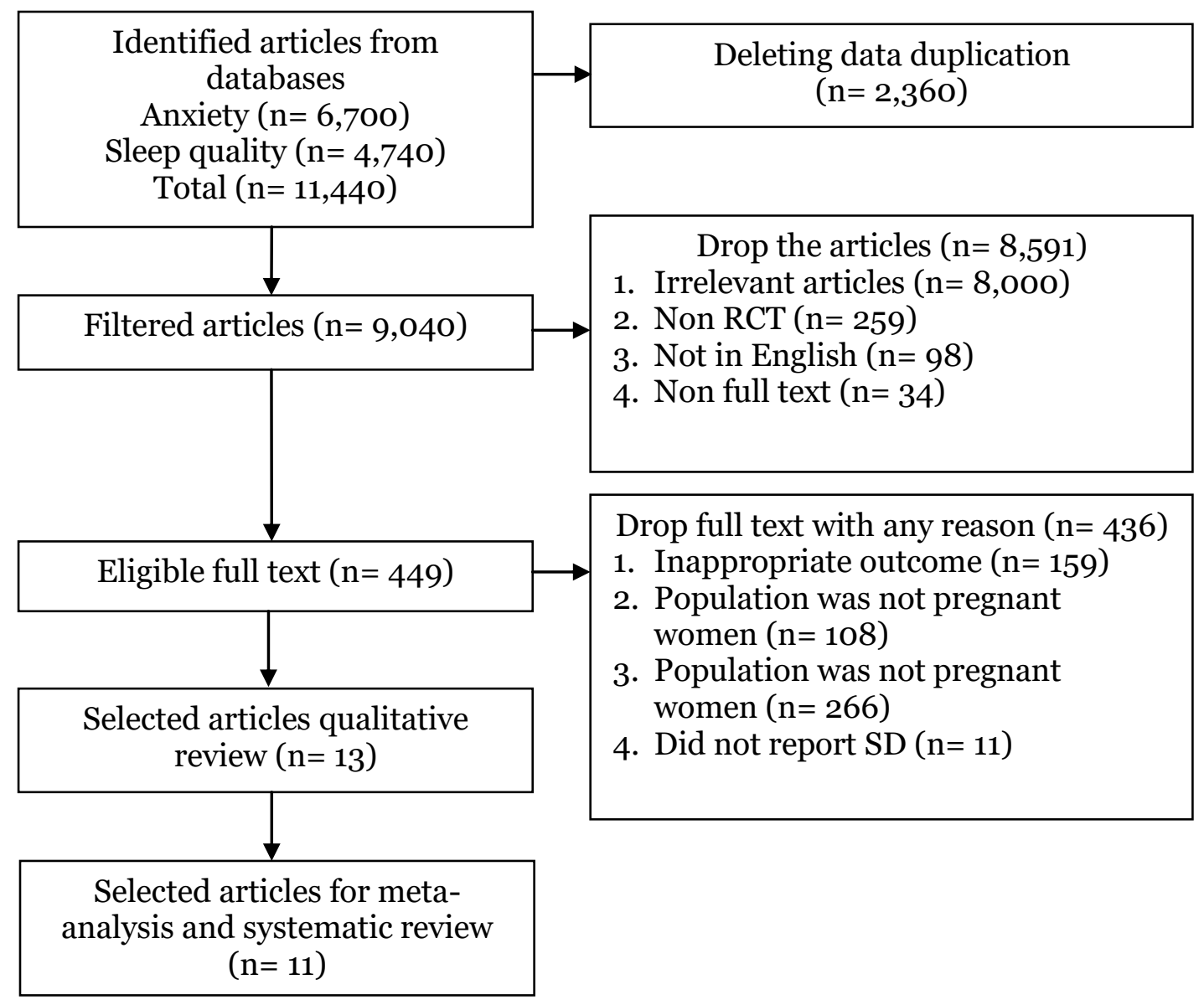

Figure 1. PRISMA flow diagram

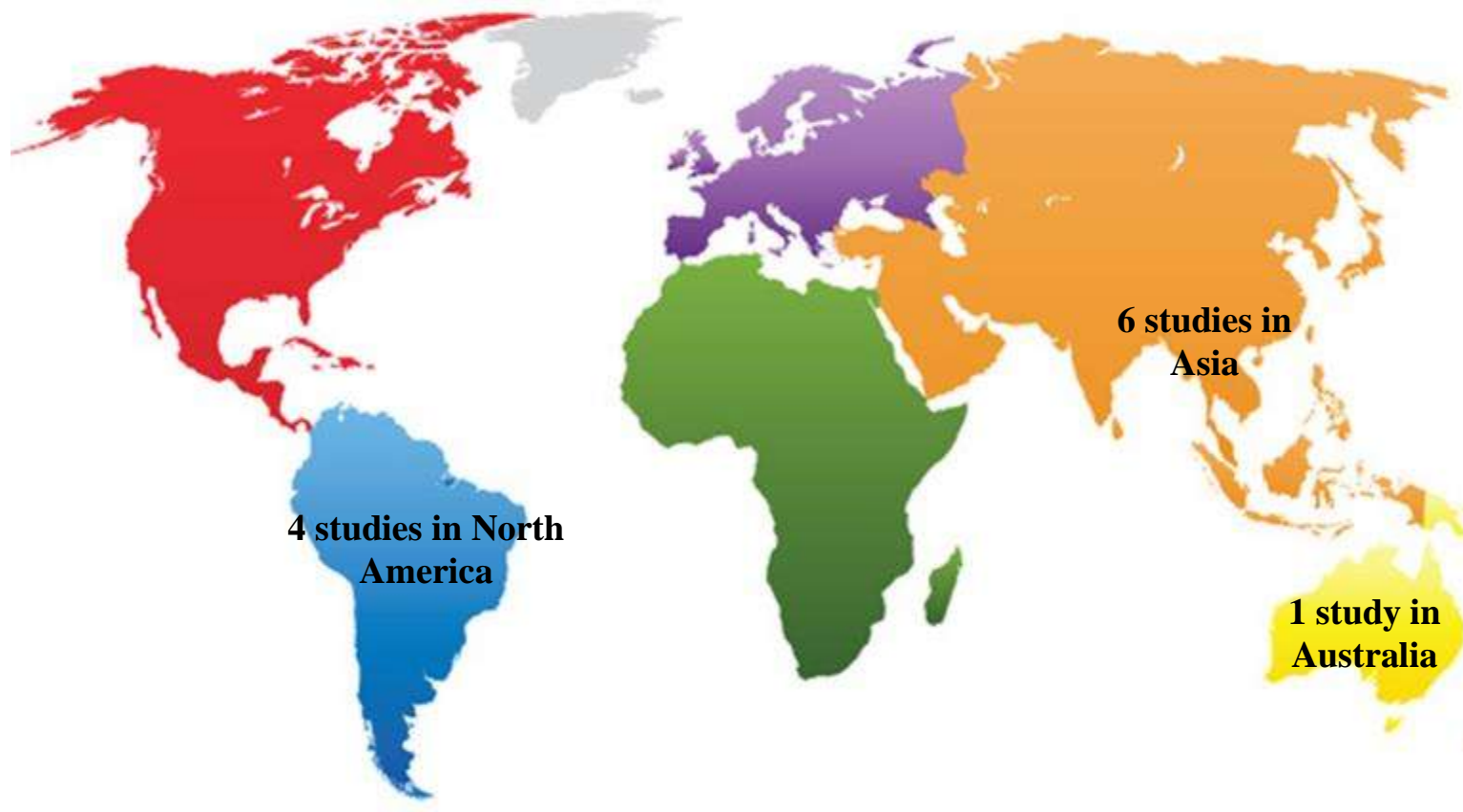

Figure 2. Map of the Research Area 
Table 1. Assessment of the Quality of Prenatal Yoga Effectiveness Study on Reducing Anxiety

\begin{tabular}{|c|c|c|c|c|c|c|c|c|c|c|c|c|c|}
\hline \multirow{2}{*}{ Author (Year) } & \multicolumn{12}{|c|}{ List of Questions Checklist } & \multirow{2}{*}{ Total } \\
\hline & $\mathbf{1}$ & 2 & 3 & 4 & 5 & 6 & 7 & 8 & 9 & 10 & $\mathbf{1 1}$ & 12 & \\
\hline Avin et al. (2018) & 1 & 1 & 1 & 1 & 1 & 1 & 1 & 1 & 1 & $\mathrm{O}$ & 0 & 1 & 10 \\
\hline Yulianti et al. (2018) & 1 & 1 & 1 & 1 & 1 & 1 & 1 & 1 & 1 & 1 & $\mathrm{O}$ & 1 & 11 \\
\hline Davis et al. (2015) & 1 & 1 & 1 & 1 & 1 & 0 & 1 & 1 & 1 & 1 & $\mathrm{O}$ & 1 & 10 \\
\hline Field et al. (2013b) & 1 & 1 & 1 & 1 & 1 & 1 & 1 & 1 & 1 & $\mathrm{O}$ & 1 & 1 & 11 \\
\hline Kundarti et al. (2020) & 1 & 1 & 1 & 1 & 1 & 0 & 1 & 1 & 1 & 0 & 1 & 1 & 10 \\
\hline Satyapriya et al. (2013) & 1 & 1 & 1 & 1 & 1 & $\mathrm{O}$ & 1 & 1 & 1 & 1 & 1 & 1 & 11 \\
\hline Bapat et al. (2016) & 1 & 1 & 1 & 1 & 1 & 1 & 1 & 1 & 1 & 0 & 0 & 1 & 10 \\
\hline Manincore et al. (2016) & 1 & 1 & 1 & 1 & 1 & $\mathrm{O}$ & 1 & 1 & 1 & 1 & $\mathrm{O}$ & 1 & 10 \\
\hline Field et al. (2013a) & 1 & 1 & 1 & 1 & 1 & 1 & 1 & 1 & 0 & 1 & 1 & 1 & 11 \\
\hline Field et al. (2012) & 1 & 1 & 1 & 1 & 1 & 1 & 1 & 1 & 1 & $\mathrm{O}$ & $\mathrm{O}$ & 1 & 10 \\
\hline
\end{tabular}

Table 2. Assessment of the Quality of Prenatal Yoga Effectiveness Study on Sleep Quality

\begin{tabular}{|c|c|c|c|c|c|c|c|c|c|c|c|c|c|}
\hline \multirow[b]{2}{*}{ Author (Year) } & \multicolumn{12}{|c|}{ List of Questions Checklist } & \multirow[b]{2}{*}{ Total } \\
\hline & $\mathbf{1}$ & 2 & 3 & 4 & 5 & 6 & 7 & 8 & 9 & 10 & $\mathbf{1 1}$ & 12 & \\
\hline Kundarti et al. (2020) & 1 & 1 & 1 & 1 & 1 & O & 1 & 1 & 1 & 0 & 1 & 1 & 10 \\
\hline Field et al. (2013a) & 1 & 1 & 1 & 1 & 1 & 1 & 1 & 1 & 1 & 1 & $\mathrm{O}$ & 1 & 11 \\
\hline Shu et al. (2018) & 1 & 1 & 1 & 1 & 1 & 1 & 1 & 1 & 1 & $\mathrm{O}$ & $\mathrm{O}$ & 1 & 11 \\
\hline
\end{tabular}

Table 3. Descriptions of primary studies of the effectiveness of prenatal Yoga on anxiety reduction entered into the metaanalysis

\begin{tabular}{|c|c|c|c|c|c|c|c|}
\hline $\begin{array}{l}\text { Author } \\
\text { (Year) }\end{array}$ & Country & $\begin{array}{c}\text { Study } \\
\text { Design }\end{array}$ & Sample & $\mathbf{P}$ & $\mathbf{I}$ & $\mathbf{C}$ & $\mathbf{O}$ \\
\hline $\begin{array}{l}\text { Avin et al. } \\
\text { (2018) }\end{array}$ & Iran & $\begin{array}{l}\text { Randomized } \\
\text { Controlled } \\
\text { Trial }\end{array}$ & $\begin{array}{l}\text { Yoga Group: } 30 \\
\text { Control Group: } \\
30\end{array}$ & $\begin{array}{l}\text { Pregnant women } \\
\text { with gestation at } \\
26-27 \text { weeks }\end{array}$ & $\begin{array}{l}\text { Prenatal Yoga exercises are } \\
\text { carried out in } 12-15 \text { sessions. Each } \\
\text { session is carried out for } 45-60 \\
\text { minutes. Yoga prenatal exercises } \\
\text { are carried out for } 4-5 \text { weeks }\end{array}$ & $\begin{array}{l}\text { Antenatal } \\
\text { care }\end{array}$ & $\begin{array}{l}\text { Levels of } \\
\text { Anxiety } \\
\text { Decrease } \\
\text { during } \\
\text { pregnancy }\end{array}$ \\
\hline $\begin{array}{l}\text { Yulianti et al. } \\
\text { (2018) }\end{array}$ & Indonesia & $\begin{array}{l}\text { Randomized } \\
\text { Controlled }\end{array}$ & $\begin{array}{l}\text { Yoga Group: } 51 \\
\text { Control Group: }\end{array}$ & Pregnant mother & $\begin{array}{l}\text { Prenatal Yoga practice is done for } \\
\text { a month with } 2 \text { follow-ups. }\end{array}$ & $\begin{array}{l}\text { No Pre- } \\
\text { natal Yoga }\end{array}$ & $\begin{array}{l}\text { Anxiety } \\
\text { Level }\end{array}$ \\
\hline
\end{tabular}




\begin{tabular}{|c|c|c|c|c|c|c|c|}
\hline & & Trial & 51 & & & practice & Decrease \\
\hline $\begin{array}{l}\text { Davis et al. } \\
\text { (2015) }\end{array}$ & $\begin{array}{l}\text { United } \\
\text { States }\end{array}$ & $\begin{array}{l}\text { Randomized } \\
\text { Controlled } \\
\text { Trial }\end{array}$ & $\begin{array}{l}\text { Yoga Group: } 23 \\
\text { Control Group: } \\
23\end{array}$ & $\begin{array}{l}\text { Pregnant women } \\
\text { with a gestational } \\
\text { age above } 28 \\
\text { weeks }\end{array}$ & $\begin{array}{l}\text { Prenatal yoga exercises are } \\
\text { carried out for } 8 \text { sessions, each } \\
\text { session for } 75 \text { minutes. }\end{array}$ & $\begin{array}{l}\text { Treatment } \\
\text { as Usual }\end{array}$ & $\begin{array}{l}\text { Anxiety } \\
\text { Level } \\
\text { Decrease }\end{array}$ \\
\hline $\begin{array}{l}\text { Kundarti et } \\
\text { al. (2020) }\end{array}$ & Indonesia & $\begin{array}{l}\text { Randomized } \\
\text { Controlled } \\
\text { Trial }\end{array}$ & $\begin{array}{l}\text { Yoga Group:30 } \\
\text { Control Group: } \\
29\end{array}$ & $\begin{array}{l}\text { Pregnant women } \\
\text { with gestational } \\
\text { age at 20-32 } \\
\text { weeks }\end{array}$ & $\begin{array}{l}\text { Yoga practice is done } 8 \text { times in } 8 \\
\text { weeks. Each session is } 90 \\
\text { minutes. }\end{array}$ & $\begin{array}{l}\text { Treatment } \\
\text { as Usual }\end{array}$ & $\begin{array}{l}\text { Anxiety } \\
\text { Level } \\
\text { Decrease }\end{array}$ \\
\hline $\begin{array}{l}\text { Satyapriya et } \\
\text { al. (2013) }\end{array}$ & India & $\begin{array}{l}\text { Randomized } \\
\text { Controlled } \\
\text { Trial }\end{array}$ & $\begin{array}{l}\text { Yoga Group: } 51 \\
\text { Control Group: } \\
45\end{array}$ & $\begin{array}{l}\text { Pregnant women } \\
\text { with gestational } \\
\text { age at 18-20 } \\
\text { weeks, }\end{array}$ & $\begin{array}{l}\text { Yoga practice is carried out when } \\
\text { pregnant women reach } 36 \text { weeks } \\
\text { of pregnancy. In a week, prenatal } \\
\text { yoga practice is carried out for } 3 \\
\text { days. }\end{array}$ & $\begin{array}{l}\text { Standart } \\
\text { antenatal } \\
\text { exercise }\end{array}$ & $\begin{array}{l}\text { Anxiety } \\
\text { Level } \\
\text { Decrease }\end{array}$ \\
\hline $\begin{array}{l}\text { Bapat et al. } \\
(2016)\end{array}$ & India & $\begin{array}{l}\text { Randomized } \\
\text { Controlled } \\
\text { Trial }\end{array}$ & $\begin{array}{l}\text { Yoga Group:20 } \\
\text { Control Group: } \\
20\end{array}$ & $\begin{array}{l}\text { Pregnant women } \\
\text { with gestational } \\
\text { age at 20-28 } \\
\text { weeks }\end{array}$ & $\begin{array}{l}\text { Yoga practice is done for } 30 \\
\text { minutes per session. Prenatal } \\
\text { yoga practice is done for } 1 \text { month. }\end{array}$ & $\begin{array}{l}\text { No } \\
\text { Prenatal } \\
\text { Yoga } \\
\text { practice }\end{array}$ & $\begin{array}{l}\text { Anxiety } \\
\text { Level } \\
\text { Decrease }\end{array}$ \\
\hline $\begin{array}{l}\text { Field et al. } \\
(2013)\end{array}$ & $\begin{array}{l}\text { United } \\
\text { States }\end{array}$ & $\begin{array}{l}\text { Randomized } \\
\text { Controlled } \\
\text { Trial }\end{array}$ & $\begin{array}{l}\text { Yoga Group: } 46 \\
\text { Control Group: } \\
46\end{array}$ & $\begin{array}{l}\text { Pregnant women } \\
\text { with gestational } \\
\text { age at } 22 \text { weeks }\end{array}$ & $\begin{array}{l}\text { Yoga exercises carried out for } 12 \\
\text { weeks, totaling } 12 \text { sessions. Each } \\
\text { session is only } 20 \text { minutes long }\end{array}$ & $\begin{array}{l}\text { No } \\
\text { Prenatal } \\
\text { Yoga } \\
\text { practice }\end{array}$ & $\begin{array}{l}\text { Anxiety } \\
\text { Level } \\
\text { Decrease }\end{array}$ \\
\hline $\begin{array}{l}\text { Field et al. } \\
\text { (2012) }\end{array}$ & $\begin{array}{l}\text { United } \\
\text { States }\end{array}$ & $\begin{array}{l}\text { Randomized } \\
\text { Controlled } \\
\text { Trial }\end{array}$ & $\begin{array}{l}\text { Yoga Group: } 46 \\
\text { Control Group: } \\
46\end{array}$ & $\begin{array}{l}\text { Pregnant women } \\
\text { with gestational } \\
\text { age at 18-22 } \\
\text { weeks }\end{array}$ & $\begin{array}{l}\text { Yoga practice was carried out for } \\
12 \text { weeks. Each week only } 1 \\
\text { session. Each session is only } 20 \\
\text { minutes long }\end{array}$ & $\begin{array}{l}\text { No } \\
\text { Prenatal } \\
\text { Yoga } \\
\text { practice }\end{array}$ & $\begin{array}{l}\text { Anxiety } \\
\text { Level } \\
\text { Decrease }\end{array}$ \\
\hline
\end{tabular}


Table 4. Descriptions of primary studies of the effectiveness of prenatal Yoga on sleep quality entered into the meta-analysis

\begin{tabular}{|c|c|c|c|c|c|c|c|}
\hline $\begin{array}{l}\text { Author } \\
\text { (Year) }\end{array}$ & Country & $\begin{array}{l}\text { Study } \\
\text { Design }\end{array}$ & Sample & $\mathbf{P}$ & I & $\mathbf{C}$ & $\mathbf{O}$ \\
\hline $\begin{array}{l}\text { Kundarti } \\
\text { et al. } \\
(2020)\end{array}$ & Indonesia & $\begin{array}{l}\text { Randomized } \\
\text { Controlled } \\
\text { Trial }\end{array}$ & $\begin{array}{l}\text { Yoga Group:30 } \\
\text { Control Group: } 29\end{array}$ & $\begin{array}{l}\text { Pregnant women with } \\
\text { gestational age at 20- } \\
32 \text { weeks }\end{array}$ & $\begin{array}{l}\text { Yoga practice is done } 8 \text { times } \\
\text { in } 8 \text { weeks. Each session is } 90 \\
\text { minutes each. }\end{array}$ & $\begin{array}{l}\text { Treatment as } \\
\text { Usual }\end{array}$ & $\begin{array}{l}\text { Improved } \\
\text { sleep quality }\end{array}$ \\
\hline $\begin{array}{l}\text { Fielda et } \\
\text { al. (2013) }\end{array}$ & $\begin{array}{l}\text { United } \\
\text { States }\end{array}$ & $\begin{array}{l}\text { Randomized } \\
\text { Controlled } \\
\text { Trial }\end{array}$ & $\begin{array}{l}\text { Yoga Group: } 46 \\
\text { Control Group: } 46\end{array}$ & $\begin{array}{l}\text { Pregnant women with } \\
\text { gestational age at } 22 \\
\text { weeks }\end{array}$ & $\begin{array}{l}\text { Yoga practice was carried out } \\
\text { for } 12 \text { weeks. Each week only } \\
1 \text { session. Each session is only } \\
20 \text { minutes long }\end{array}$ & $\begin{array}{l}\text { Without } \\
\text { prenatal yoga } \\
\text { practice }\end{array}$ & $\begin{array}{l}\text { Improved } \\
\text { sleep quality }\end{array}$ \\
\hline $\begin{array}{l}\text { Shu et al. } \\
(2018)\end{array}$ & China & $\begin{array}{l}\text { Randomized } \\
\text { Controlled } \\
\text { Trial }\end{array}$ & $\begin{array}{l}\text { Yoga Group: } 52 \\
\text { Control Group: } \\
50\end{array}$ & $\begin{array}{l}\text { Pregnant women in } \\
\text { the first until the third } \\
\text { trimester }\end{array}$ & $\begin{array}{l}\text { Yoga practice was carried out } \\
\text { for } 4 \text { weeks. Each week only } 1 \\
\text { session. Each session only } \\
\text { takes } 60 \text { minutes. }\end{array}$ & $\begin{array}{l}\text { Providing } \\
\text { education }\end{array}$ & $\begin{array}{l}\text { Improved } \\
\text { sleep quality }\end{array}$ \\
\hline
\end{tabular}

\section{Forest Plot}

\begin{tabular}{|c|c|c|c|c|c|c|c|c|c|}
\hline \multirow[b]{2}{*}{ Study or Subgroup } & \multicolumn{3}{|c|}{ Prenatal Yoga } & \multicolumn{3}{|c|}{ Non Prenatal Yoga } & \multirow{2}{*}{ Weight } & Std. Mean Difference & \multirow{2}{*}{$\begin{array}{c}\text { Std. Mean Difference } \\
\text { N, Random, } 95 \% \mathrm{Cl}\end{array}$} \\
\hline & Mean & SD & Total & Mean & SD & Total & & N, Random, $95 \% \mathrm{Cl}$ & \\
\hline Avin 2018 & 24.87 & 4.5 & 30 & 37.84 & 6.4 & 30 & $9.7 \%$ & $-2.31[-2.98,-1.65]$ & $\rightarrow-1$ \\
\hline Bapat 2016 & 43.2 & 5.66 & 20 & 42.7 & 7.69 & 20 & $9.8 \%$ & $0.07[-0.55,0.69]$ & \\
\hline Field 2012 & 42.6 & 8.85 & 42 & 38.96 & 9.11 & 42 & $10.2 \%$ & $0.40[-0.03,0.83]$ & + \\
\hline Field A 2013 & 46.1 & 7.9 & 46 & 44.3 & 11.4 & 46 & $10.2 \%$ & $0.18[-0.23,0.59]$ & \\
\hline Field B 2013 & 45.5 & 8.2 & 46 & 46.1 & 8.5 & 46 & $10.2 \%$ & $-0.07[-0.48,0.34]$ & \\
\hline Kundarti 2020 & 13.16 & 7.31 & 30 & 35.3 & 20.76 & 29 & $9.9 \%$ & $-1.41[-1.99,-0.84]$ & $\rightarrow$ \\
\hline Manincore 2016 & 9.08 & 7.02 & 37 & 12.56 & 9.65 & 38 & $10.1 \%$ & $-0.41[-0.86,0.05]$ & $\Rightarrow$ \\
\hline Satyapriya 2013 & 30.12 & 5.72 & 51 & 39.71 & 6.8 & 45 & $10.1 \%$ & $-1.52[-1.98,-1.07]$ & $\rightarrow$ \\
\hline Yulianti 2018 & 13.22 & 3.16 & 51 & 23.86 & 3.55 & 51 & $9.9 \%$ & $-3.14[-3.73,-2.56]$ & $\rightarrow$ \\
\hline Total $(95 \% \mathrm{Cl})$ & & & 376 & & & 370 & $100.0 \%$ & $-0.84[-1.53,-0.16]$ & \\
\hline \multicolumn{9}{|c|}{$\begin{array}{l}\text { Heterogeneity: } \operatorname{Tau}^{2}=1.15 ; \mathrm{Chi}^{2}=168.12, \mathrm{df}=9(\mathrm{P}<0.00001) ; \mathrm{I}^{2}=95 \% \\
\text { Test for overall effect: } Z=2.41(P=0.02)\end{array}$} & $\begin{array}{ccccc}-4 & -2 & 0 & 2 & 4 \\
\text { natal Yoga } & \text { Non Pren }\end{array}$ \\
\hline
\end{tabular}

Figure 3. Forest plot of prenatal yoga effectiveness in reducing anxiety 


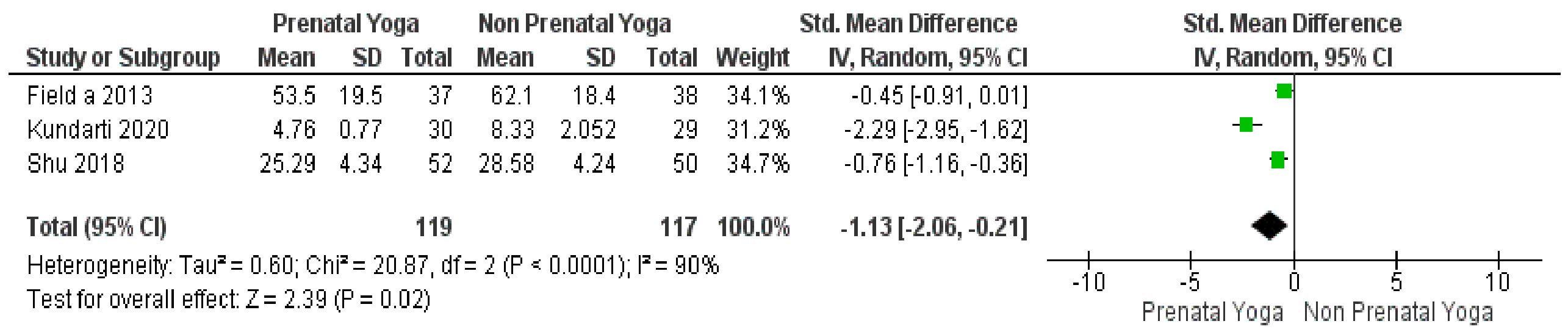

Figure 4. Forest plot of the prenatal yoga effectiveness on sleep quality

\section{Funnel Plot}

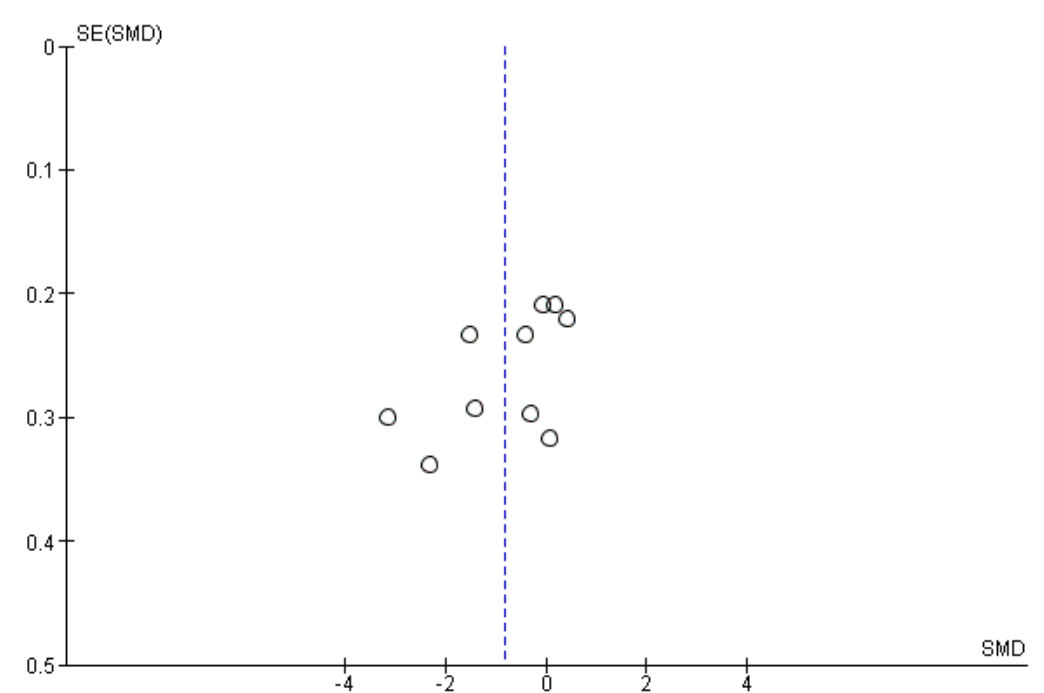

Figure 5. Funnel plot of Prenatal Yoga Effectiveness on Anxiety Decrease 


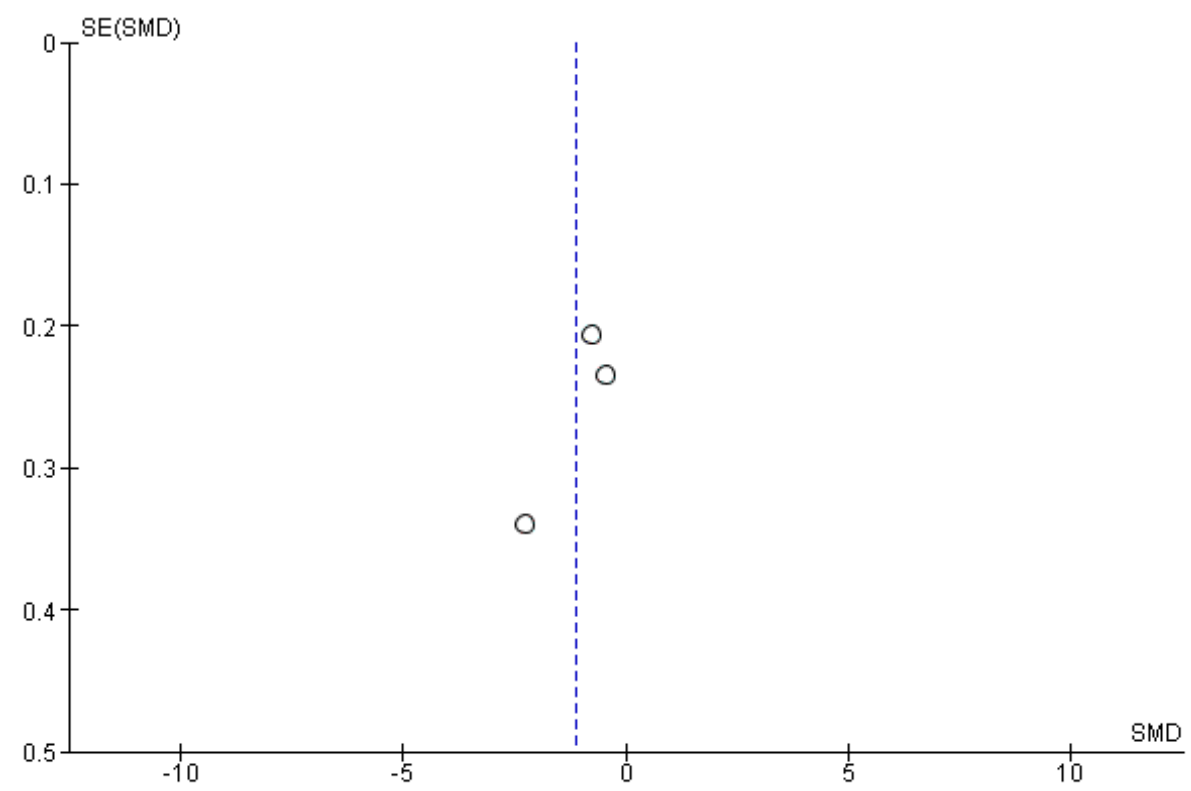

Figure 6. Funnel plot of Prenatal Yoga Effectivenesson sleep quality

The plot on the left of the graph had a standard error between 0.2 and 0.4 and the plot on the right had a standard error between 0.2 and 0.4. Bias also occurred from the imbalance between the distances between studies on both the right and left of the funnel plot. Meanwhile, the funnel plot about the effectiveness of prenatal Yoga on sleep quality (Figure 6) showed a publication bias characterized by the asymmetry of the right and left plots where 2 plots were on the right and 1 plot was on the left. The plot on the left of the graph had a standard error between 0.3 and 0.4 and the plot on the right had a standard error between 0.2 and o.3. Bias also occurs from the imbalance between the distances between studies on both the right and left of the funnel plot.

\section{DISCUSSION}

This systematic review and meta-analysis study raises the theme of prenatal Yoga's effectiveness on sleep quality and anxiety decrease during pregnancy. The dependent variables analyzed were sleep quality and anxiety during pregnancy.

Research that discusses prenatal Yoga on reducing anxiety and sleep quality du- ring pregnancy is considered important because this research is still very rare. The number of relevant researches published and accessible is still small and has data access problems (data duplication) (Murti, 2018).

Most of these studies still used a quasi-experimental study design and not a randomized controlled trial. Besides that, most of the statistical results reported did not include the mean and standard deviation and only included the p-value results.

Confounding factors affect the relationship or effect of exposure to the occurrence of the disease estimated (estimated) by the study is not the same as the relationship or effect that occurs in the target population, or the study results are invalid (incorrect) (Murti, 2018).

This systematic study and meta-analysis research use research that controls the confounding factor, which can be seen from the study inclusion criteria, namely using a randomized controlled trial research design. The statistical results of each study include a standardized mean difference.

Estimates of the combined effect of prenatal Yoga on anxiety and sleep quality 
were processed using RevMan 5.3 with the continuous method. This method was used to analyze the effect size or standardized mean difference in the two groups of bivariate data controlled for confounding factors by randomization. The results of systematic studies and meta-analyses are presented in a forest plot and funnel plot (Murti, 2018).

\section{Decreased Anxiety}

The forest plot results show that prenatal yoga practice could reduce anxiety 0.84 times compared to without prenatal yoga practice $(\mathrm{SMD}=-0.84 ; 95 \% \mathrm{CI}-1.53$ to $0.16 \mathrm{p}=0.020$ ).

This is in line with a study by Davis et al. (2015), which stated the hypothesis of this study that participants in the yoga group would show changes in anxiety symptoms over time compared to participants in the treatment as usual group. The statistical test results showed significant difference between the two groups at posttest. Anxiety shows a downward trend over time, but it occurs but is not significant.

The pathophysiology of prenatal Yoga on anxiety is the pranayamic breathing movement, also known as deep breathing, which is defined as a deliberate breath movement used in every yoga practice (Jerath et al., 2006). Slow, slow, deep breathing activates the parasympathetic nerve, responsible for stretching the tissues in the lungs and vagal nerve.

Besides, a positive correlation was shown by Asana (Yoga Postures) in increasing levels of Gamma Amino Butyric Acid (GABA) in the brain and increasing mood scores and reducing anxiety. Factors that play an important role in reducing anxiety during meditation are increased parasympathetic activity, GABA levels and serotonin, and reduced levels of serolus locus with decreased nonadrenaline hormones and decreasing cortisol (Joshi \& Sousa, 2014).

\section{Sleep Quality}

The forest plot results showed that prenatal yoga practice could improve sleep quality $(\mathrm{SMD}=-1.13 ; 90 \% \mathrm{CI}-2.06$ to $-0.21 \mathrm{p}=$ 0.020). The minus results on SMD show an increase in sleep quality. The instruments used were the Pitsburg Quality Sleep Instrument and Self-Rated Sleep Scale.

PSQI is a questionnaire that shows the prevalence of sleep disorders and/or insomnia in pregnancy. The PSQI consists of 19 question items. The component scores range from o (no difficulty) to 3 (severe difficulty) and, when added together, yield a global score ranging from $\mathrm{O}$ to 21. A score $>5$ indicates disturbed sleep (Dietch et al., 2016).

A score on SRSS $\geq$ of 23 points was considered to have sleep problems. Total questionnaires on the SRSS were 200, 197 valid questionnaires were returned with an efficiency level of 98.5\% (Liu et al., 2015). So, the Standardized Mean Difference of the effectiveness of prenatal Yoga on sleep quality was 1.13 units higher than that of not doing prenatal Yoga.

This is in line with a study by Kundarti et al. (2020), which stated that sleep quality measurements were carried out twice before and after the intervention (week 8), the average quality of sleep for intervention and control $(M=4.76)$ with the intervention $(M=8.33)$. This suggests that yoga practice can improve the quality of life for pregnant women.

The pathophysiology of prenatal Yoga on sleep quality is the pranayama movement. This movement activates autonomic nerve responses and decreases cortisol levels. Besides that the pranayama movement has also been shown to reduce sleep disorders commonly experienced by pregnant women (Babbar et al., 2016). Variations in 
Aflahiyah et al./ Effectiveness of Prenatal Yoga on Sleep Quality and Reduction of Anxiety

hormone levels caused by physical activity such as Growth Hormone Receptor (GHR), melatonin, interleukin-1, prolactin, and prostaglandin D2 have the desired modulation effect on sleep quality (Veqar and Ejaz, 2012).

\section{AUTHOR CONTRIBUTION}

Shiva was the principal researcher who selected the topic, searched, and collected research data. Didik Gunawan Tamtono and Hanung Prasetya played a role in analyzing data and reviewing research documents.

\section{CONFLICT OF INTEREST}

There was no conflict of interest in this study.

\section{FUNDING AND SPONSORSHIP}

This study used private funds from the main researcher.

\section{ACKNOWLEDGEMENT}

The authors would like to express their gratitude to the database providers PubMed, Science Direct, Springer Link, Google Scholar, Chocrane Library.

\section{REFERENCE}

Avin A, Khojasteh F, Ansari H (2017). The effect of yoga on anxiety in pregnant women in their first pregnancy of Zahedan City in 2017. Spec J Med Res Health Sci. 3(4): 24-31. https://sciarena.com/en/article/the-effect-of-yoga-on-anxiety-in-pregnant-womenin-their-first-pregnancy-of-zahedancity-in-2017.

Babbar S, Shyken J (2016). Yoga in pregnancy. Clin Obstet Gynecol. 59(3): 600-612. https://doi.org/10.1097/grf.ooooooooooooo210.

Bapat RA, Kumari S, Nagendra HR (2016). The effect of one month yoga inter- vention on perceived stress and anxiety in pregnant women. $\mathrm{J}$ Womens Health, Issues Care. 5: 3. doi:10.4172/2325-9795.1000233.

Beddoe AE, Lee KA, Weiss SJ, Kennedy HP, Yang CPP (2010). Effects of mindful Yoga on sleep in pregnant women: a pilot study. Biological research for nursing, 11(4): 363-370. https://doi.org/10.1177/1099800409 356320.

Davis K, Goodman SH, Leiferman J, Taylor M, Dimidjian S (2015). A randomized controlled trial of Yoga for pregnant women with symptoms of depression and anxiety. Complementary therapies in clinical practice. 21(3): 166172. https://doi.org/10.1016/j.ctcp.2015.06.005.

Dietch JR, Taylor DJ, Sethi K, Kelly K, Bramoweth AD, Roane BM (2016). Psychometric evaluation of the PSQI in US college students. Journal of Clinical Sleep Medicine, 12(8): 11211129. https://doi.org/10.5664/jcsm.6050.

Field T, Diego M, Delgado J, Medina L (2012). Yoga and social support reduce prenatal depression. Anxiety and cortisol. J Bodyw Mov Ther. 17(4): 397-403. https://doi.org/10.1016/j.jbmt.2013.03.010.

Field T, Diego M, Delgado J, Medina L (2013). Tai chi/yoga reduces prenatal depression, anxiety and sleep disturbances. Complementary therapies in clinical practice, 19(1): 6-10.

Field T, Diego M, Hernandez-Reif $M$, Medina L, Delgado J, Hernandez A (2012). Yoga and massage therapy reduce prenatal depression and prematurity. Journal of bodywork and movement therapies, 16(2): 204-209. https://dx.doi.org/10.1016\%2Fj.jbmt. 2011.08.002. 
Aflahiyah et al./ Effectiveness of Prenatal Yoga on Sleep Quality and Reduction of Anxiety

Joshi A, De Sousa A (2012). Yoga in the management of anxiety disorders. Sri Lanka Journal of Psychiatry, 3(1). https://www.researchgate.net/deref/ http\%3A\%2F\%2Fdx.doi.org\%2F10.40 38\%2Fsljpsyc.v3i1.4452.

Kundarti FI, Titisari I, Sepdianto TC (2020). Effect of prenatal yoga on anxiety, cortisol and sleep quality. Journal of Critical Reviews, 7(13): 655661. https://doi.org/10.31838/ijpr/2020.12.03.315.

Liu C, Xie H, Zhang X, Yu Y, Zhang X, Sun $\mathrm{Y}$, Wang $\mathrm{H}$ (2015). Health related management plans improve sleep disorders of patients with chronic liver disease. International journal of clinical and experimental medicine, 8(6): 9883. https://www.ncbi.nlm.nih.gov/pubmed/26309672.

Manincor M, Bensoussan A, Smith CA, Barr K, Schweickle M, Donoghoe LL, Fahey $P$ (2016). Individualized yoga for reducing depression and anxiety, and improving wellbeing: A randomized controlled trial. Depression and anxiety, 33(9): 816-828. https://doi.org/10.1002/da.22502.

Mazel S, Murkoff M (2012). Schwangerschaft und Geburt: Alles, was Sie wissen müssen. MVG Verlag.

Murti B (2018). Prinsip dan metode riset epidemiologi. Surakarta: Program Studi Ilmu Kesehatan Masyarakat, Program Pascasarjana, Universitas Sebelas Maret.

Satyapriya M, Nagarathna R, Padmalatha $V$, Nagendra HR (2013). Effect of integrated Yoga on anxiety, depression \& well being in normal pregnancy. Complementary therapies in clinical practice, 19(4): 230-236. https://doi.org/10.1016/j.ctcp.2013.06.003.
Shu L, Xi M, Wu C, Zhao W, Tan C, Chen D (2018). Effects of mindfulness yoga training on sleeping, anxiety and childbirth fear among pregnant women. Chin Nur Manage. 18(10): 1422-7.

Silva MMDJ, Nogueira DA, Clapis MJ, Leite EPRC (2017). Anxiety in pregnancy: prevalence and associated factors. Revista da Escola de Enfermagem da USP.

Soto-Balbuena C, Rodriguez M, Escudero Gomis AI, Ferrer Barriendos FJ, Le HN, Pmb-Huca G (2018). Incidence, prevalence and risk factors related to anxiety symptoms during pregnancy. Psicothema, 30(3): 257-63. https://doi.org/10.7334/psicothema2017.379.

Uguz F, Yakut E, Aydogan S, Bayman MG, Gezginc K (2019). Prevalence of mood and anxiety disorders during pregnancy: A case-control study with a large sample size. Psychiatry Res. 272: 316-318. https://doi.org/10.1016/j.psychres.2018.12.129.

Yulianti I, Respati SH, Sudiyanto A (2018). The effect of prenatal Yoga on anxiety and depression in Kudus, Central Java. J Matern Child Health. 3(2): 100-104. https://doi.org/10.26911/thejmch.2018.03.02.02\%20.

Veqar Z, Hussain ME (2012). Sleep quality improvement and exercise: A Review. Int J Sciencific Res Publications, 2(8): 1-8.

Zwan JE, de Vente W, Tolvanen M, Karlsson H, Buil JM, Koot HM, Karlsson L (2017). Longitudinal associations between sleep and anxiety during pregnancy, and the moderating effect of resilience parallel process latent growth curve models. Sleep Med. 40: 63-68. https://doi.org/10.1016/j.sleep.2017.08.023. 